\title{
Legal aspects of cruise medicine - can a non-US ship's doctor be sued for malpractice in Florida?
}

\section{Eilif Dahl}

Department of Occupational Medicine, Haukeland University Hospital, Norwegian Centre for Maritime Medicine, Bergen, Norway

\begin{abstract}
An English ship's doctor treated a non-US female patient for abdominal discomfort on a foreign-flagged cruise ship off the coast of Haiti. In Mexico the patient underwent abdominal surgery, followed by complications, for which her lawyers wanted to take the ship's doctor to court in Florida, USA.

A trial court granted their wish, but this decision was reversed on appeal as the factors discussed were insufficient to establish Florida jurisdiction over the ship's doctor.

The decision is not about whether malpractice occurred; it is about limiting the possibility of taking the ship's doctor to a court in a location preferred by the plaintiffs' lawyers. The appeal court ruling is important for non-US doctors working as independent contractors on cruise vessels that visit US ports, and it will hopefully prevent some of the more frivolous law suits from being filed in the future.
\end{abstract}

(Int Marit Health 2014; 65, 1: 13-15)

Key words: ship's doctor, cruise ship, Florida jurisdiction, maritime medicine

\section{INTRODUCTION}

Although the majority of cruise passengers are Americans, hardly any cruise vessels are registered in the USA and most ship's doctors are non-US citizens. Unfortunately, fear of harassment by US lawyers and frivolous US law suits keep many competent doctors away from interesting and challenging careers at sea. A Florida appeal court decision has recently confirmed and clarified jurisdiction limitations for non-US ship's doctors [1].

\section{CASE}

A non-US female patient presented with abdominal discomfort in the medical centre on a foreign-flagged cruise ship off the coast of Haiti. An English ship's doctor treated her for the abdominal complaint. At that time it was not felt to be clinically necessary to evacuate the patient to a hospital in Haiti or Dominican Republic by helicopter. The patient subsequently disembarked the ship at the next available port and went to a Mexican hospital. She underwent abdominal surgery, followed by complications, for which her lawyers later blamed the ship's doctor. For various reasons the lawyers wanted to take the doctor to court in Florida [2]. But can they?

\section{LIABILITY FOR MEDICAL NEGLIGENCE}

Cruise ship doctors are not always technically employed by their respective lines. So long as the shipping company has hired a competent medical doctor, the law does not make the shipping company responsible for the medical actions of the ship board doctor [3]. The Federal Maritime Law rule that the ship owner cannot be held vicariously liable for negligence of the ship's doctor directed at the ship's passengers [Barbetta v. S/S Bermuda Star, 848 F2d 1364 ( $5^{\text {th }}$ Cir. 19880]. The Florida Supreme Court has upheld that same rule, finding that a cruise line is not liable for the negligent treatment of a passenger by a shipboard doctor [Carnival Corp. v. Carlisle, 953 So. 2d 461, 470 (Fla. 20070] [4].

There is presently a legal debate concerning whether a cruise line can be held liable for a ship's doctor's action if the passenger believes that the doctor is an agent for the cruise company. It should be noted that on most ships the 
doctor(s) are 'independent contractors'; they are available aboard to provide a service for the passengers, they make medical decisions on their own and administer treatment on their own [4].

\section{INDIVIDUAL PHYSICIAN LIABILITY}

Ship's doctors can be personally sued for their actions aboard the ship. The question on where they can be sued is unclear. Some judges had suggested that the doctors subject themselves to the jurisdiction of the ship's home port. At a minimum, a doctor can sometimes be sued where the alleged malpractice occurred. However, when the patient has been treated in international waters, the doctor likely can be sued only where he or she lives. The mere act of being a ship's physician serving on a ship that regularly calls on the Port of Miami is not sufficient for a Florida Court to exercise jurisdiction over that physician; either the alleged malpractice must occur in Florida's waters or the doctor must have a substantial connection to Florida [4].

\section{FLORIDA JURISDICTION}

In the present case, no allegations were made in the Amended Complaint regarding any medical treatment performed by the ship's doctor with respect to the patient either in the State of Florida or within Florida territorial waters, but the lawyers claimed 'a strong connection' between the ship's doctor and the State of Florida [2].

The ship's doctor's lawyers then moved to quash service of process, to dismiss for lack of personal jurisdiction and to dismiss for failure to state a cause of action. The doctor, a British citizen who does not live in Florida, does not own real property in Florida and who is not licensed to practice in Florida, participated in jurisdictional discovery - i.e., responding to jurisdictional interrogatories and attending a deposition via Skype [1].

\section{TRIAL COURT RULING ON JURISDICTION}

However, on October $16^{\text {th }}, 2012$, the court denied the motion to dismiss for lack of personal jurisdiction, finding that while specific jurisdiction did not exist over the ship's doctor 'under Florida's long arm statute', it nevertheless had general jurisdiction over him under the following provision of the statute: 'A defendant who is engaged in substantial and not isolated activity within this state, whether such activity is wholly interstate, intrastate, or otherwise, is subject to the jurisdiction of the courts of this state, whether or not the claim arises from that activity' [§ 48.193(2), Fla. Stat. (2011)] (emphasis added).

The court based its finding of general jurisdiction on the following contacts between the ship's doctor and the State of Florida, all of which relate to his 9-year career as a shipboard doctor: entering into employment agreements in Florida with Florida-based cruise lines, attending annual medical conferences in Florida and from time to time making presentations at same, receiving advanced cardiac life support recertification in Florida, spending holiday from time to time in Florida, having 2 bank accounts in Florida, and working aboard a cruise ship that embarked/disembarked at a Florida port 1 day a week. In addition, because for all intents and purposes the ship's doctor worked and resided exclusively on a cruise ship, the trial court felt compelled to relax both the stringent jurisdictional standard required under Florida's long arm statute and the constitutional analysis set forth in the well-established case law in order to redress what it "clearly deemed a nefarious scheme by the doctor to avoid being sued not only in a Florida court, but in any court' (emphasis added) [1].

\section{APPEAL COURT RULING ON JURISDICTION}

On appeal, in a 2-1 decision the Third District Court of Appeal reversed the trial court holding that the factors discussed above were insufficient to establish jurisdiction over the ship's doctor [1]. Setting aside the trial court's opinion that the ship's doctor has consciously engaged in a 'shell game to thwart jurisdiction', it furthermore ruled that none of the factors relied upon by the trial court, whether viewed individually or collectively, are sufficient to confer general jurisdiction over him. Indeed, contrary to the trial court's expressed desire to employ a relaxed, "broader" view of general jurisdiction, it is well settled that "the requirement of continuous and systematic general business contacts establishes a 'much higher threshold' than the 'minimum contacts' required to assert specific jurisdiction" [1].

Moreover, the Appeal Court went on to point out that attending annual industry conferences in Florida and securing medical certifications issued by the State of Florida during those conferences also do not confer general jurisdiction, nor does spending holiday in Florida or having a Florida bank account. The ship's doctor is a citizen of Great Britain where he was born, raised, attended medical school, and still has a family. He has never resided in Florida; he has never owned or rented real property in Florida; he is not licensed to practice medicine here; and he has never owned or operated a business (or medical practice) in this state [1].

The crux of the matter was therefore the fact that the foreign-flagged vessel on which the doctor worked returns to its Florida home port for the embarkation/debarkation process 1 day a week, during which time the doctor may or may not see passengers and crew members in some limited capacity as a shipboard physician.

To this end, the record established that the ship's medical centre is closed on the morning on which the ship returns to its Florida home port to disembark passengers. However, should an emergency arise while the ship is returning to port, 
emergency treatment is rendered by the ship's doctor who may be on duty at the time:

"Generally speaking, the ship's medical center is closed when the ship is in (...) the home port day. (...) There will be occasions when emergencies happen (...) on the last few hours of the cruise - prior to arrival, where emergency care has to be rendered". The ship's medical center then remains closed until some unspecified time during the evening after the ship has left port. And, while the ship's doctor on duty would provide emergency medical care to either passengers or crew while the ship is departing, the medical clinic was open for that $1 \mathrm{~h}$ on the evening of departure primarily to care for crew members since passengers generally would not have been on board long enough to become seriously ill [1].

Thus, while there is no evidence that the ship's doctor actually treated any passenger or crew member while in Florida or its territorial waters, the evidence shows that it is likely, as the ship's doctor candidly admitted, that he rendered emergency treatment to someone in Florida territorial waters while coming into or going out of port [1].

However, comparing with several similar cited cases, the Appeal Court concluded that the doctor's contacts with the State of Florida were not sufficient to confer general jurisdiction over him and therefore reversed the order denying his motion to dismiss for lack of personal jurisdiction (emphasis added) [1].

\section{COMMENTS}

This is an important ruling for non-US doctors working as 'independent contractors' on cruise vessels that visit American ports. The decision is not about whether malpractice occurred; it is about the possibility of taking the ship's doctor to court in a location preferred by the plaintiffs' lawyers. These lawyers lost this battle, but on their website they call the decision of the appeal court 'shameful'. Despite the appeal court finding this to be 'far from an established fact on this record', the website repeats the claim that the doctor 'not only intentionally played a shell game to thwart jurisdiction in Florida, but he engaged in a nefarious scheme to avoid being sued in any court'. Furthermore, it suggests indirectly that he was not 'highly trained', 'educated' nor 'experienced' [2]. On the plaintiffs' lawyers' website the doctor will look guilty until proven innocent and he may feel that he never had the chance to defend his actions and clear his name as now there will be no trial. But would he really want one?

Having worked with the ship's doctor in question and on several occasions been exposed to US lawyers commonly known in the USA as 'ambulance chasers' (in Florida: 'cruise line chasers'), I'm clearly biased. However, in my opinion these civil law suits are not about justice and they are not about proper medical practice; they are mostly money making schemes for plaintiff lawyers. Judging by their websites $[2,3]$, they seem to hunt for cases where the ship's doctor might be sued no matter what he did or did not do. If the doctor in the present case had referred his patient to a hospital in Haiti (!) or had attempted a complicated evacuation from the ship, the plaintiffs' lawyers would likely claim that action to be just as wrong ('the patient would have been better off on board until the next port'). And subsequently, the ship's doctor would have been blamed for whatever happened to the patient later. A classic deposition question comes to mind: "Have you now stopped beating your wife? - Please answer only YES or NO".

The goal of the lawyers in many cases is simply to make so much noise, that the cruise company will agree to quietly settle out of court to avoid further negative media attention, without even considering if any wrong was done - an activity bordering on blackmail.

Why are the plaintiffs' lawyers in this case still slamming the court and the ship's doctor on their website, although they lost?

One reason might be pure revenge: they lost and now take it out on the perceived winners. A second reason might be that they are publicly trying to defend themselves and justify their loss to their disappointed clients by blaming incompetent judges and the scheming doctor. And, thirdly, they may try to intimidate and scare a very knowledgeable and experienced ship's doctor with an excellent medical reputation from practicing on ships again and thus eliminate a formidable opponent in future law suits against cruise lines. Hopefully, they will not succeed.

\section{REFERENCES}

1. Third District Court of Appeal - State of Florida, July Term, A.D. 2013 (Opinion filed December 4, 2013). No. 3D12-3045, Lower Tribunal No. 11-16507. http://www.3dca.flcourts.org/opinions/3D12-3045. pdf (accessed 20 February 2014).

2. Walker J. Shell Game. http://www.cruiselawnews.com (Posted 04 December 2013, accessed 21 February 2014).

3. Lipcon CR. Should Cruise Lines Be Held Liable for Their Onboard Doctor's Medical Malpractice Incidents? Part 2. In: Cruise Passenger S.O.S., Cruise Ship Law and Maritime Matter of the Week. http:// blog.lipcon.com/2013/12/cruise-lines-held-liable-onboard-doctorsmedical-malpractice-incidents-part-2.html (Posted on 12 December 2013, accessed 21 February 2014).

4. Mase CJ. Legal Aspects of Maritime Medicine. Mase Lara Eversole (http://www.mletrial.com), Miami 2012. 